\title{
Investigations on Glucose Uptake in Isolated Human Leucocytes from Normal and Diabetic Subjects*
}

\author{
A. Englhardt and Th. Metz** \\ 2. Medizinische Universitätskliniz und Diabetes-Forschungsinstitut an der Universität Düsseldorf
}

(Prof. Dr. K. Oberdisse)

Received: June 2, 1970, accepted: March 29, 1971

Summary. 1. Leucocyte preparations have been obtained from the blood of 135 healthy control persons and 10 poorly-controlled insulin-dependent diabetics according to a procedure described earlier. Cells were suspended in a Krebs-Ringer-Bicarbonate-Buffer. Glucose uptake, lactate production and cell glucose space were determined after incubating the cells for $1 \mathrm{~h}$ at $37^{\circ} \mathrm{C}$ in an atmosphere of $\mathrm{O}_{2} / \mathrm{CO}_{2}(95 / 5)$. Extracellular water-space of the cell sediment was corrected by measuring $\mathrm{U}-{ }^{11} \mathrm{C}$-sucrose levels in the medium before and after addition to the cell sediment. -2 . The cells showed intact structures and amoeboid motility under the light-microscope as well as under the phase-contrast-microscope. During an incubation lasting $1 \mathrm{~h}$, the ATP/ADP quotient diminished by about $20 \%$; the following metabolites: glucose-6-phosphate, fructose-1,6-diphosphate, 1,3-phosphoglycerate, pyruvate and lactate increased slightly up to markedly, especially glucose-6-phosphate and lactate. - 3. Sources of methodological errors were investigated in preliminary experiments. Disregarding corrections for the extracellular space of the cell sediments led to a dilution effect which imitates an apparent glucose uptake. For measurements of intracellular glucose and cell glucose space the procedure of Crofford and Renold provided the best results. Falsely high values for cell glucose have been found using the glucose oxidase reaction. - 4. Glucose uptake of healthy leucocytes increases at first steeply, later on less with rising medium glucose concentrations. Addition of insulin $(50-500 \mathrm{mU} / \mathrm{ml})$ gave no consistent effects. At medium glucose concentrations of 400 and $600 \mathrm{mg} / 100 \mathrm{ml}$ intracellular glucose could be demonstrated with statistical significance. Intracellular glucose and cell glucose space were not affected by insulin to any marked degree. Determinations of lactate production indicated that human leucocytes utilize the largest portion of glucose via glycolysis. - 5. At medium glucose concentrations of $600 \mathrm{mg} / 100 \mathrm{ml}$ leucocytes from diabetics who had received no insulin for $14 \mathrm{~h}$ prior to incubation showed a significant diminution of glucose uptake. -6 . Theoretical curves for inward transport and phosphorylation have been calculated from the data for glucose uptake and intracellular glucose concentration.

Recherches sur l'accumulation de glucose dans des leuco. cytes humains isolés chez des sujets sains et des diabétiques

Résumé. 1. Des préparations de leucocytes ont été faites selon une méthode antérieurement décrite à partir du sang de 135 sujets sains et 10 diabétiques insulinodépendants et mal contrôlés. Les cellules ont été suspendues dans un tampon Krebs-Ringer-bicarbonate. L'accumula. tion de glucose, la formation de lactate, l'espace glucidique cellulaire ont été mesurés après une incubation d'une

* Supported by Deutsche Forschungsgemeinschaft. ** The authors are greatly indepted to Prof. Wilbrandt, Department of Pharmacology, University Bern, for advice and discussion. heure des cellules à $37^{\circ}$ dans $95 / 5 \%$ de $\mathrm{O}_{2} / \mathrm{CO}_{2}$. La correction de l'espace extra-cellulaire du culot cellulaire a été faite par la mesure du sucrose-U. ${ }^{14} \mathrm{C}$ dans le milieu avant et après addition au culot cellulaire. - 2. Au microscope ordinaire et au microscope de contraste de phases, les cellules ont montré des structures intactes et une mobilité amiboide. Le quotient ATP/ADP a diminué de $20 \%$ au cours de l'incubation d'une heure, et les métabolites glucose-6-phosphate, fructose-1.6- diphosphate, 1.3-phosphoglycerate, pyruvate et lactate ont plus ou moins augmenté, lo glucose-6-phosphate et le lactate dans la plus forte proportion. - 3. Les erreurs méthodiques ont été contrôlées par des recherches antérieures. L'absence de correction do l'espace extra-cellulaire du culot cellulaire produit un effet de dilution qui donne la fausse impression d'une accumulation de glucose. Les méthodes selon Crofford et Renold ont donné les meilleurs résultats en ce qui concerne la mesure du glucose intra-cellulaire et l'espace glucidique cellulaire. Des résultats faussement positifs ont été décelés par la mesure du glucose des cellules en utilisant la méthode de glucose-oxydase. - 4 . L'accumulation de glucose par les cellules provenant de sujets sains a augmenté $d^{3}$ abord fortement, puis plus légèrement en présence de concentrations croissantes de glucose. L'addition de l'insuline n'a pas eu d'effet dé. celable. Le glucose intra-cellulaire a pu être mis en évidence de façon statistiquement significative pour des concentrations de glucose de 400 à $600 \mathrm{mg} \%$. Le glucose intra-cellulaire et l'espace glucidique cellulaire n'ont pas été influencés avec certitude par l'insuline. La mesure de la formation de lactate a montré que la plus grande partie du glucose dans les leucocytes humains est utilisée pour la glycolyse. - 5. Chez les diabétiques qui n'ont pas eu d'insuline $14 \mathrm{~h}$ avant l'incubation, il est apparu une diminution significative de l'accumulation de glucose en présence d'une concentration de $600 \mathrm{mg} \%$ de glucose dans le milieu. - 6. Pour le transport à l'intérieur et pour la phosphorylation, des courbes méthodiques ont été calculées d'après les valeurs de l'accumulation du glucose et d'après les concentrations du glucose intra-cellulaire.

Untersuchungen über die Glucose-Aufnahme von isolierten menschlichen Leukocyten von normalen und diabetischen Personen

Zusammenfassung. 1. Aus dem Blut von 135 Gesunden und 10 schlecht eingestellten insulinbedürftigen Diabetikern wurden Leucocytenpräparationen nach einem bereits früher beschriebenen Verfahren hergestellt. Die Zellen wurden in Krebs-Ringer-Bicarbonat-Puffer suspendiert. Glucose-Aufnahme, Lactatbildung und Zellglukosespace wurden am Ende einer einstündigen Incubation der Zellen bei $37^{\circ}$ in $\mathrm{O}_{2} / \mathrm{CO}_{2}(95 / 5)$-Atmosphäre gemessen. Die Korrektur für den extracellulären Wasserraum des Zellsediments erfolgte durch Messung von Sucrose-U.14C im Medium vor und nach Zugabe zum Zellsediment. - 2. Die Zellen zeigten im Lichtmikroskop wie im Phasenkontrastmikroskop intakte Strukturen und amöboide Beweglich- 
keit. Der ATP/ADP-Quotient nahm während einer 1stündigen Incubation um etwa $20 \%$ ab, die Metabolite Glucose-6-Phosphat, Fructose-1,6-diphosphat, 1,3-Posphoglycerat, Pyruvat und Lactat stiegen gering bis deutlich an, am stärksten Glucose-6-phosphat und Lactat. - 3. In Voruntersuchungen wurden Fehlerquellen der Methodik überprüft. Vernachlässigung der Korrektur für den extracellulären Raum der Zellsedimente führte zu einem Verdünnungseffekt, der als scheinbare Glucoseaufnahme gemessen wurde. Für die Messung' der intracellulären Glucose und des Zellglucosespace zeigte die Methode nach Crofford und Renold die besten Resultate. Falsch hohe Werte wurden durch Messung der Zellglucose mit der Glucoseoxydasereaktion gefunden. 4. Die Glucoseaufnahme Stoffwechselgesunder stieg bei steigenden Mediumglucosekonzentrationen zunächst steil, dann zunehmend langsamer an. Zusatz von Insulin $(50-500 \mathrm{E} / \mathrm{ml})$ war ohne sicheren Einfluß. Intracelluläre Glucose konnte statistisch signifikant bei Mediumglukosekonzentrationen von 400 und $600 \mathrm{mg} \%$ nachgewiesen werden. Intracelluläre Glucose und Zellglucosespace wurden durch Insulin nicht sicher beeinflußt. Die Messung der Lactat-Bildung zeigte, daß in menschlichen Leucocyten der größte Teil der Glucose über die Glycolyse utilisiert wird. -5 . Bei Diabeti. kern, die $14 \mathrm{Std}$. vor der Incubation kein Insulin mehr erhalten hatten, zeigte sich bei einer Mediumglucosekonzentration von $600 \mathrm{mg} \%$ eine signifikante Abnahme der Glucoseaufnahme. - 6. Aus den Daten der Glucoseaufnahme und intracellulären Glucosekonzentration wurden theoretische Kurven für Einwärtstransport und Phosphorylierung berechnet.

Key-words: Lencocytes, glucose uptake, intracellular glucose
It is difficult to obtain suitable tissues for studies in vitro of the metabolic problems in human diabetes. The assertion by several authors (Dunn [19], Kalant and Schucher [14]) that human leucocytes may have an insulin-dependent glucose metabolism is therefore of special interest, although the reports of different teams are unequivocal. Whereas some investigators were able to demonstrate a significant insulin effect (Weinberg and Field [24]), others found this to hold true only in diabetics (Kalant and Schucher [14]) or during special experimental conditions (Esman [12], Martin et al. [18]).

Glucose utilization in isolated human leucocytes from normal and diabetic subjects has therefore been reassessed. During these studies we found several sources for methodological errors that can affect glucose results in isolated cell systems, which will also be described in this article. The investigations were aimed at answering the question whether human leucocytes are a suitable tissue for the study of diabetes mellitus.

\section{Methods}

Patients. Blood samples for the preparation of leucocytes were obtained from 135 control subjects with normal metabolism. Prior to the withdrawal of blood, all subjects had been fasting for $12 \mathrm{~h}$ and resting for at least $1 \mathrm{~h}$. In addition, blood samples from 10 poorly controlled, insulin-dependent diabeties were examined. At the time of examination the blood sugar levels exceeded $200 \mathrm{mg} /$ $100 \mathrm{ml}$ and glycosuria was higher than $10 \mathrm{~g} /$ day. 8 of these patients were acidotic. Their last insulin dose (regular insulin) had been received $14 \mathrm{~h}$ prior to blood withdrawal.

Reagents. Sucrose U-14 C, spec. activity $10.6 \mathrm{mCi} / \mathrm{mM}$ and $\mathrm{H}_{2} \mathrm{O}^{3} \mathrm{H}$, was obtained from Buchler \& Co. Regular insulin (Hoechst), $40 \mathrm{U} / \mathrm{ml}$, was diluted to concentrations from 0.05 to $0.5 \mathrm{U} / \mathrm{ml}$ with Krebs-Ringer bicarbonate buffer (Umbreit).

The following reagents (Biochemica Boehringer) were used for glucose determinations: NADP, oxidized form, di-sodium salt (NADP enzym. 85\%), ATP cryst. di-sodium salt (ATP-Na $\times 3 \mathrm{H}_{2} \mathrm{O} 98 \%$, ATP enzym. $82 \%$, $\mathrm{ADP}+\mathrm{A}-5$-MP enzym. 1\%), hexokinase, (spec. activity ca. $140 \mathrm{U} / \mathrm{mg}$, GR, 6-PGDH and PGluM each $0.01 \%$, 6-GPDH and MK each $0.02 \%$, PGl $0.1 \%$ ), G-6-PDH (spec. activity ca. $140 \mathrm{U} / \mathrm{mg}$, PGluM $0.01 \%$, 6-PGDH
$0.02 \%$, PGl $0.05 \%$, GR and HK 0.4\%). Perchloric acid for deproteinization $0.33 \mathrm{~N}$ (Biochemica Boehringer). Glucose p.a. purissime had been obtained from Merck, Darmstadt.

Preparation of leucocytes. Principle and method have been described fully elsewhere (Englhardt 1964 [11]).

Incubation. After washing $\mathbf{3}$ times, the cell sediment obtained by the procedure described (Englhardt 1964 [11]) was suspended in Krebs-Ringer bicarbonate buffer. Before adding the cells, the buffer was gassed for 10 min with $\mathrm{O}_{2} / \mathrm{CO}_{2}(95 / 5)$. Additions consisted of glucose in isotonic solution (KRB-buffer) (for final concentrations see tables and figures); Sucrose-U.- ${ }^{14} \mathrm{C}$, final concentration $0.2-0.4 \mu \mathrm{Ci} / \mathrm{ml} ; \mathrm{H}_{2} \mathrm{O}^{3} \mathrm{H}$, final concentration $23-46$ $\mu \mathrm{Ci} / \mathrm{ml}$; and non-labelled sucrose as carrier, final concen. tration $1 \mathrm{mg} / \mathrm{ml}$. Before addition of the medium to the cell sediment the activities of sucrose-U-14 $\mathrm{C}$ and $\mathrm{H}_{2} \mathrm{O}$ ${ }^{3} \mathrm{H}$ in the medium were determined. For this purpose the medium was diluted to $1: 11$, or $1: 21$ with $0.33 \mathrm{~N}$ perchloric acid, and glucose was determined in these dilutions. Using sterile, closed glass vessels the cell susponsion was divided into four portions and thereafter incubated for $60 \mathrm{~min}$ at $37^{\circ} \mathrm{C}$. After the incubation the suspensions were centrifuged for $1.5 \mathrm{~min}$ at $800 \times g$, and glucose and radioactivity determined in the supernatant. After removal of the supernatant, a defined volume of $0.33 \mathrm{~N}$ perchloric acid was added to the cell sediment, which was then homogenized for $1 \mathrm{~min}$ in the Whirl-Mix. After removal of the sediment by centrifugation, glucose and radioactivity were again determined in the supernatant. The cell-number of the suspensions was counted four times in different pipettes before incubation.

Analyses. Glucose was determined enzymatically with hexokinase and glucose-6-phosphate-dehydrogenase. Sucrose- $\mathrm{U}_{-}{ }^{14} \mathrm{C}$ and $\mathrm{H}_{2} \mathrm{O}-{ }^{3} \mathrm{H}$ were measured in the PackardScintillation-Counter, Model 3003. For this purpose $0.2 \mathrm{ml}$ of the solution were added to $15 \mathrm{ml}$ of Bray's scintillation fluid [1]. ${ }^{14} \mathrm{C}$ and ${ }^{3} \mathrm{H}$-activities were separated according to Träger ${ }^{1}$. Correction for quenching was performed using external standards. Lactate was determined after neutralization of the supernatant with $\mathrm{x} / 2$ ice-cold trap$\mathrm{K}_{2} \mathrm{CO}_{3}$-solution (1 $\mathrm{M}$ Triethanolamine-HCl, $1.3 \mathrm{M} \mathrm{K}_{2} \mathrm{CO}_{3}$ ), final $\mathrm{pH} 6.9-7.0$ and centrifugation of the perchlorate sediment after $10 \mathrm{~min}$ incubation in iced water. Lactate was estimated according to Hohorst. Pyruvate, glucose-6phosphate, fructose-1.6-diphosphate, ATP, ADP and AMP were determined in the same extract with the method described by Hohorst, Kreutz and Bücher [13] (for methodological details see Table 1).

1 Reported in the manual to Packard Scintillation Counter. 
Calculations. 1. Glucose Uptake. Glucose uptake was defined as disappearance of glucose from the medium as $\mu \mathrm{mol} / 10^{10}$ cells $/ \mathrm{h}$. Corrections for the extracellular water space were made by measuring sucrose-U- ${ }^{14} \mathrm{C}$ in the medium before and after addition to the cell sediment. Calculations were exclusively based on extracellular distribution of labelled sucrose (for explanation see "methods"). Glucose uptake $\left(\mu \mathrm{mol} / 10^{10} \mathrm{cells} / \mathrm{h}=\right.$ true medium glucose $t_{0}(\mu \mathrm{mol} / \mathrm{ml})$ - medium glucose $t_{60}$ $(\mu \mathrm{mol} / \mathrm{ml})$

$$
\text { number of cells } / \mathrm{ml} \times 10^{-10}
$$

true medium glucose $t_{0}(\mu \mathrm{mol} / \mathrm{ml})=$

medium glucose $(\mu \mathrm{mol} / \mathrm{ml}) \times{ }^{14} \mathrm{C} \mathrm{cpm} \mathrm{medium} t_{0}$

$$
{ }^{14} \mathrm{C} \text { epm medium }
$$

Values at $t_{0}$ represent the situation immediately after addition of the cell sediment. The direct measurement of these parameters is jeopardized by several sources of gross methodological errors (adsorption of glucose to cell membranes, rapid diffusion into cells). The results were therefore calculated on the basis of sucrose distribution data.

Table 1

Part a

Substrate content of isolated leucocytes before and after incubation in Krebs-Ringer-Bicarbonate-Medium containing glucose $(0.011 M) 0.011 \mathrm{M}$ glucose, $p H$ 7.4, temperature $37^{\circ} \mathrm{C}$, gas phase $95 \% \mathrm{O}_{2}+5 \% \mathrm{CO}_{2}$

\begin{tabular}{lcc}
\hline & \multicolumn{2}{l}{$\begin{array}{l}60 \text { min incubation } \\
\text { before }\end{array}$} \\
after \\
\hline Glucose-6-phosphate & $11.0 \pm 2.9$ & $26.0 \pm 6.9$ \\
Fructose-1,6-disphos- & & \\
phate & $4.6 \pm 2.0$ & $5.8 \pm 2.7$ \\
1,3-phosphoglycerate & $7.1 \pm 1.4$ & $8.4 \pm 3.6$ \\
Pyruvate & $0.45 \pm 0.06$ & $0.9 \pm 0.06$ \\
Lactate & $4.5 \pm 2.1$ & $25.6 \pm 2.2$ \\
ATP & $40.8 \pm 8.7$ & $40.2 \pm 9.5$ \\
ADP & $16.3 \pm 3.6$ & $20.1 \pm 4.5$ \\
AMIP & $31.7 \pm 7.2$ & $26.1 \pm 4.8$ \\
\hline
\end{tabular}

Part $\mathbf{b}$

ATP/ADP quotient in isolated human leucocytes during incubation for 6 h. Pre-incubation value was obtained by logarithmic plotting of different quotients vs. time. The value for the time before preparation was obtained from this straight line by extrapolation

\begin{tabular}{cl}
\hline ATP/ADP quotient vs. time: & Quotient \\
\hline before preparation & 3.00 \\
$t_{0}$ & $2.50 \pm 0.33$ \\
$t_{60}$ & $2.00 \pm 0.42$ \\
$t_{120}$ & $1.65 \pm 0.19$ \\
$t_{180}$ & $1.41 \pm 0.22$ \\
$t_{240}$ & $1.19 \pm 0.17$ \\
\hline
\end{tabular}

Calculation of intracellular glucose and glucose-space. The intracellular glucose concentration was assessed using' the following formula:

Intrac. glucose $(\mu \mathrm{mol} / \mathrm{ml})=$ cell glucose $(\mu \mathrm{mol})$ - extracell. glucose ( $\mu \mathrm{mol})$ intracellular water content $(\mathrm{ml})$ $=\frac{G_{H}\left(V_{G}+V_{P}\right)-G_{M} \times V_{E}}{V_{I}}$
$G_{H}=$ homogenate glucose $(\mu \mathrm{mol} / \mathrm{ml})$

$G_{M}=$ medium glucose $(\mu \mathrm{mol} / \mathrm{ml})$, true medium glucose

$V_{G}=$ total water content of cell sediment in $\mathrm{ml}\left(V_{E}+V_{I}\right)$

$V_{E}=$ extracellular water content of cell sediment (ml)

$V_{I}=$ intracellular water content of cell sediment $(\mathrm{ml})$

$V_{P}=$ volume of cell sediment

Calculation of water spaces $V_{G}, V_{E}$ and $V_{I}$ :

Calculations are based on the assumption of a symme. trical distribution of $\mathrm{H}_{2} \mathrm{O}-{ }^{3} \mathrm{H}$ in medium and cell-water. This results in

$$
\begin{gathered}
\quad \begin{array}{c}
{ }^{{ }^{3} \mathrm{H} \text { cpm medium }} \\
V_{G} \mathrm{H} \text { cpm homogenate }
\end{array}=\frac{V_{G}+V_{P}}{V_{G}} \\
\text { and } V_{E}=\frac{{ }^{3} \mathrm{H} \text { cpm homogenate } \times V_{P}}{{ }^{3} \mathrm{cpm} \text { medium }-{ }^{3} \mathrm{H} \mathrm{cpm} \text { homogenate }} \\
V_{I}=V_{G}-V_{E} .
\end{gathered}
$$

Calculation of cell glucose space. The cell glucose space corresponds to the volume of cell water which contains glucose in a concentration equal to that of the medium. Calculations are made using the following formula: cell glucose space $(\mathrm{ml} / \mathrm{ml}$ cell water $)=$ intracellular glucose ( $\mu \mathrm{mol} / \mathrm{ml}$ cell water) medium glucose $(\mu \mathrm{mol} / \mathrm{ml})$

Calculations for the demonstration of transport and phos. phorylation processes. The rates of the membrane transport and phosphorylation of glucose were calculated according to Post, Morgan, and Park (1961) [23]. Several modifications have been introduced. Since intracellular glucose has not been found at glucose concentrations below $200 \mathrm{mg} /$ $100 \mathrm{ml}$, transport rate and glucose uptake are assumed to be identical at these concentrations. The extent of out ward transport occurring at higher medium concentra. tions can be estimated under the assumption that glucose is transported through the cell membrane in both directions at the same rate. It is therefore possible to estimate also the rate of inward transport at higher concentrations where glucose uptake and inward transport do not correspond any longer since intracellular glucose has accumulated. As a rough approximation, the extent of outward transport can be estimated from the lower part of the curve of glucose uptake, if, as described by Park, one assumes a state "without membrane", at which the inside and outside concentrations are equal and if the intracellular glucose concentration is to equal the external one. By plotting this value (sum of glucose uptake + outward transport) a curve for inward transport is obtained.

Since the rate of inward transport decreases with higher external concentrations, it was checked whether the curve corresponds to Michaelis-Menten kinetics. This calculation could only be based on data corresponding to true inward transport, i.e. glucose uptake under conditions without accumulation of intracellular glucose. Kinetic constants for inward transport were obtained from these data which were necessary for the plotting of a theoretical curve for inward transport.

$l / v$ was plotted against $l / s$ after calculation of the regression lines of all reciprocals for $v$ against all reciprocals for $s$ using the method of least squares.

$x=l / s$ then corresponded to medium glucose and $y=l / v$ to glucose uptake.

$K_{m}$ and $V_{\max }$ were obtained from:

$$
l / v=\left(l / V_{\max }\right)+\left(K_{m} / V_{\max }\right) \times l / s
$$

using the regression equations

$$
\begin{gathered}
x(y=0)=l / K_{m}=\frac{b \bar{x}-\bar{y}}{b} \\
y(x=\mathbf{0})=l / V_{\max }=y+b x
\end{gathered}
$$


The constants thus obtained were inserted into the transport equation (Post, Morgan and Park 1961 [23], Wilbrandt 1950/51, 1957, 1959, 1961) [25-28].

If this process corresponds to Michaelis-Menten kinetics, the rate of glucose passage from outward to inward can be expressed as:

$$
\frac{V=V_{\max }\left(G_{e}\right)}{G_{e}+K_{m}}
$$

$\mathrm{V}$ corresponding to the transport rate at a given medium glucose concentration $G_{e}$. If the hypothesis proves correct that the process is governed by Michaelis-Menten kinetics, a curve predicting inward transport is obtained [7].

Phosphorylation was calculated from glucose uptake corrected for the amount of glucose accumulated in the cell.

Statistically significant differences were calculated according to Doerffel [6].

\section{Results}

\section{Preliminary methodical investigations}

1. Characteristics of leucocyte preparations. a) Morphology. Under the phase-contrast microscope, the cells showed intact structures and amoeboid motility. These observations were made over several hours. Cells, incubated for several hours in buffer solutions, have also been examined. Even after incubation amoeboid motility was clearly demonstrable in all cells. Results have since been published elsewhere [10, 11].

b) Metabolism of isolated cells. The ATP/ADP quotient of the cell preparations was determined during a four-hour incubation. The value preceding preparation, obtained by extrapolation, falls into the range reported by Kreutz, Hohorst and Bücher [13] in liver tissue. There was a slow but continuous decrease during the incubation. The metabolites glucose-6-phosphate, fructose-1,6-disphosphate, 1,3-phosphoglycerate, pyruvate and lactate rose slightly to markedly. This was the case particularly with glucose-6-phosphate and lactate (Table 1). The results indicate that during incubation the glycolytic transfer is inhibited beyond the hexokinase reaction. Since total glucose metabolism in leucocytes occurs predominantly by glycolysis (see below), an accumulation of lactate sets in. Glucose uptake at a medium glucose concentration of $200 \mathrm{mg} /$ $100 \mathrm{ml}$, measured at intervals of $30 \mathrm{~min}$, was constant during the first $60 \mathrm{~min}$, then declined progressively (Table 8).

2. The reference system. Comparing leucocyte numbers arrived at with the counting chamber and with the Coulter Counter (Coulter Electronics) indicated that the methodological error was of the same magnitude for both procedures, but that electronic counting constantly resulted in lower figures. We assume that the apparatus registers small particles present in the solution and consisting of cell aggregates as single cells. Since variance of protein determination in cell homogenates was more pronounced than that of cell counting, we finally reverted to the leucocyte counts of the suspension obtained by using the counting chamber.

3. Reproducibility of metabolic data. We calculated the extent of the analytical error for glucose and isotopes and also the total error for the metabolic data: glucose uptake, cell water content and intracellular glucose. Using different assays, variation coefficients from 5.8 to 10.4 were obtained for these metabolic data. Since there is a relatively marked variation for the results of the group, we must assume a large biological variability of these metabolic parameters.

4. Sources of methodological errors. a) Measurements of glucose uptake. Glucose uptake is calculated in the usual way from the difference of medium glucose at the beginning and end of the experiment. During determinations of glucose uptake on isolated cells, there is a dilution effect by the extracellular water content of the cell sediment which will give the picture of an apparent glucose uptake and can lead to gross errors. By adding U-14C-sucrose to the medium it was possible to demonstrate that immediately after the addition of the cells to the medium a decrease of medium glucose results which is not due to an accelerated uptake or glucose adsorption but represents a dilution effect. True medium glucose values, determined after the addition of the cells or calculated using $\mathrm{U}^{14} \mathrm{C}$ sucrose, are within the range of methodological error (Table 2).

Table 2. Changes of medium glucose concentration by the extracellular water content of the cell sediment

\begin{tabular}{llcrccc}
\hline $\mathrm{G}_{1}$ & $\mathrm{G}_{2}$ & \multicolumn{2}{c}{$\mathrm{G}_{1}-\mathrm{G}_{2}\left(\mathrm{G}_{2} / \mathrm{G}_{1}\right) \cdot 100$} & $\mathrm{G}_{2}$ & \multicolumn{2}{c}{$\mathrm{G}_{1}-\mathrm{G}_{2}\left(\mathrm{G}_{2} / \mathrm{G}_{1}\right) \cdot 100$} \\
\hline $\mathbf{1 7 6}$ & $\mathbf{1 6 1}$ & 15 & 91.5 & 159 & 17 & 90.3 \\
406 & $\mathbf{3 7 5}$ & $\mathbf{3 1}$ & 92.4 & 378 & 28 & 93.1 \\
$\mathbf{5 2 6}$ & 485 & 41 & 97.3 & 483 & 43 & 91.8 \\
$\mathbf{5 8 7}$ & $\mathbf{5 7 1}$ & 16 & 97.3 & 578 & 9 & 98.5 \\
618 & 604 & 14 & 97.0 & 601 & 17 & 97.2 \\
823 & $\mathbf{7 8 5}$ & $\mathbf{3 8}$ & 95.4 & 774 & 49 & 90.4 \\
& & & $\bar{x} 93.4$ & & & $\bar{x} 93.6$
\end{tabular}

$\mathrm{G}_{1}$ medium glucose concentration in $\mathrm{mg} / 100 \mathrm{ml}$ before addition of the medium to the cell sediment.

$\mathrm{G}_{2}$ medium concentration after addition of the medium to the cell sediment.
A results for glucose determined before and immediately after addition of cells.

B results for glucose calculated from the U. ${ }^{14} \mathrm{C}$-sucrose activity of the medium. 
In Table 3 results for glucose uptake of leucocytes, depending on medium glucose concentration with and without correction for dilution are compared. It appears that - especially with high medium glucose concentrations - a relatively high apparent glucose uptake results. The correction factor diminishes with increasing leucocyte concentration of the suspension (Table 4). As a result, glucose uptake values appear to depend on the cell concentration of the suspension. Similar effects have been noticed and reported by other authors. The possibility of such mechanism being responsible should be discussed.

Table 3. Glucose uptake of human leucocytes with and without correction for dilution

\begin{tabular}{lrlc}
\hline $\begin{array}{l}\text { medium glu- } \\
\text { cose } \\
\mathrm{mg} / 100 \mathrm{ml}\end{array}$ & $n$ & \multicolumn{2}{l}{ glucose uptake } \\
$\mu \mathrm{mol} / 10^{10}$ cells/h & $\begin{array}{l}\text { apparent glucose } \\
\text { uptake }\end{array}$ \\
\hline 200 & 21 & $423 \pm 59$ & $574 \pm 95$ \\
\hline 400 & 8 & $433 \pm 76$ & $1087 \pm 390$ \\
\hline 500 & 8 & $471 \pm 90$ & $1173 \pm 566$ \\
\hline 600 & 8 & $484 \pm 86$ & $1450 \pm 599$ \\
\hline
\end{tabular}

A glucose uptake as the difference of medium glucose $t_{0}$ $t_{60}$.

$B$ glucose uptake as corrected considering the $\mathrm{U}^{14} \mathrm{C}$ sucrose activity of the medium.

Table 4. Influence of number of leucocytes on the calculation of corrected and non-corrected glucose uptake

\begin{tabular}{llll}
\hline $\begin{array}{l}\text { Number of } \\
\text { cells/ml sus- } \\
\text { pension }\end{array}$ & $\begin{array}{l}\text { corrected glu- non-corrected } \\
\text { cose uptake } \\
\mu \text { mol/h/10 } / 10 \\
\text { cells }\end{array}$ & $\begin{array}{l}\text { glucose up- } \\
\text { take } \mu \text { mol/h/hence be- } \\
10^{10} \text { cells }\end{array}$ & $\begin{array}{l}\text { tween cor- } \\
\text { rected and } \\
\text { non-corrected } \\
\text { glucose up- } \\
\text { take }\end{array}$ \\
\hline $1.42 \times 10^{7}$ & 533 & 1630 & 1097 \\
$1.97 \times 10^{7}$ & 511 & 1220 & 709 \\
$2.42 \times 10^{7}$ & 522 & 1040 & 518 \\
$3.40 \times 10^{7}$ & 402 & 906 & 504 \\
$7.00 \times 10^{7}$ & 339 & 527 & 188 \\
$7.62 \times 10^{7}$ & 371 & 556 & 185 \\
\hline
\end{tabular}

Medium glucose concentration $600 \mathrm{mg} / 100 \mathrm{ml}$. Correction using the dilution factor as determined with ${ }^{14} \mathrm{C}$ sucrose. Data from 6 individal experiments.

b) Intracellular water space. The intracellular water space was calculated from the difference between total water space determined with $\mathrm{H}_{2} \mathrm{O}_{-}{ }^{3} \mathrm{H}$ and the extracellular space measured with $\mathrm{U}_{-14}{ }^{14} \mathrm{C}$-sucrose using the method by Crofford and Renold. (1965) [4].

For comparison, in another series we determined the difference between wet and dry weight of aliquots of the cell sediment.

This last mentioned procedure gave higher results than the isotope method since the determination of wet weight includes also some remaining extracellular fluid. The reproducibility of the isotope method has been tested by comparative determinations by Crofford and Renold [4] using different isotope pairs on rat adipose tissue. They found identical values for ${ }^{14} \mathrm{C}$-sorbitol space, for $\mathrm{H}_{2} \mathrm{O}-{ }^{3} \mathrm{H}$ space and for 3-0methyl-glucose- ${ }^{14} \mathrm{C}$ space. We tested the applicability of this method to leucocyte preparations by determining the quotient: ${ }^{14} \mathrm{C} / \mathrm{H}_{2} \mathrm{O}-{ }^{3} \mathrm{H}$ during an incubation period of several hours. No change of this quotient, which would indicate an uptake of labelled sucrose into cells, was found. Falsely low values for the extracellular space by alterations of the ${ }^{14} \mathrm{C}$-activity in the medium were therefore not to be expected.

c) Intracellular glucose. Intracellular glucose was measured according to the methods indicated by Crofford and Renold [4] for rat adipose tissue and by Morgan et al. [20] for rat heart muscle. In a comparative series, determinations on cells which had been isolated, washed and disintegrated with perchloric acid were carried out adhering to Lacko's procedure [17]. This procedure showed a markedly higher variance than the isotope method. Another disadvantage was the fact that sugar transport could not be entirely stopped during washing, which lasted several minutes, and therefore sugar from the cells accumulated in the washing fluid. Sufficient cooling to stop this process was not feasible for methodological reasons. We obtained falsely high values using the glucose oxidase method (Table 5). This fault has already been mentioned

Table 5. Comparative determination of intracellular glucose with glucose oxidase and hexokinase (GOD and $H K$ )

\begin{tabular}{clccc}
\hline medium glucose & \multicolumn{4}{l}{ intracellular glucose } \\
mg/100 ml & GOD-HK $n$ \\
& GOD & HK & \\
\hline 0 & $\mathbf{5 7 5}$ & $\mathbf{0}$ & 575 & $\mathbf{3}$ \\
200 & 607 & $\mathbf{5}$ & 602 & 7 \\
600 & 971 & 83 & 888 & 4 \\
\hline
\end{tabular}

Table 6. Influence of increasing glucose concentrations in the medium on glucose uptake, intracellular glucose concentration, glucose space and lactate production in isolated human leucocytes

medium glucose up- intracell. glucose lactate proglucose take glucose space duction $\mathrm{mg} / 100 \mathrm{ml} \quad \mu \mathrm{mol} / 10^{10} \mathrm{mmol}$ $t_{0} \quad$ cells $/ \mathrm{h}$

\begin{tabular}{rrlll}
\hline 25 & $88(35)$ & n.m. & - & $56(8)$ \\
100 & $229(94)$ & n.m. & - & $385(34)$ \\
200 & $423(59)$ & 0.22 & $20^{*}$ & $623(52)$ \\
400 & $433(152)$ & 2.28 & $103^{*}$ & $881(60)$ \\
600 & $484(86)$ & 4.18 & $125^{*}$ & $910(208)$ \\
\hline
\end{tabular}

Experimental details and calculations see "Methods". Values marked by a sign are not consistently reproducible because of marked variance.

n.m. = not measurable.

* Values marked by an asterisk are significantly different from zero.

* $p$ below 0.01 . 
by Morgan, Henderson, Regen and Park [19]. The substances participating in the reaction have been identified by Partridge [22] as maltose and glycogen.

\section{Results}

\section{A. Healthy Control Subjects}

1. Intracellular water content. Intracellular water space of leucocytes from healthy control subjects, as determined by the double isotope method, was $420 \pm 100 \mu \mathrm{l} / 10^{\circ}$ cells (Table 7). It did not change

Table 7. Cell water content of human leucocyles from control persons and diabetics after incubation with and without in. sulin $(0.1 \mathrm{U} / \mathrm{ml})$

\begin{tabular}{lllll}
\hline Group & $\begin{array}{l}\text { insulin in } \\
\text { the } \\
\text { medium }\end{array}$ & $\begin{array}{l}\text { medium } \\
\text { glucose } \\
\mathrm{mg} / 100 \mathrm{ml}\end{array}$ & $\begin{array}{l}\text { cell water content } \\
\mu l / 10^{9} \text { cells }\end{array}$ \\
\hline a) controls & 6 & - & 200 & $449 \pm 130 \mathrm{n} . \mathrm{s}$. \\
b) controls & 6 & & 200 & $420 \pm 143$ \\
c) controls & 8 & - & 600 & $422 \pm 111$ \\
d) diabetics 6 & - & 600 & $329 \pm 95$ n.s. \\
e) diabetics 6 & + & 600 & $298 \pm 84$ n.s. \\
\hline
\end{tabular}

favourable for the determination and calculation of intracellular glucose.

2. Glucose uptake. With increasing glucose concentrations in the medium there is at first a steep, later a progressively slower rise in glucose uptake (Fig. 1).

Experimentally it was not possible to obtain the maximal value for uptake since there is marked variance at glucose concentrations above $600 \mathrm{mg} /$ $100 \mathrm{ml}$. No influence of insulin addition was observed at doses of 100 and $500 \mathrm{mU} / \mathrm{ml}$. Even at a medium glucose concentration of $600 \mathrm{mg} / 100 \mathrm{ml}$ no insulin effect could be demonstrated. Glucose uptake was inhibited significantly by the addition of $5 \times 10^{-3} \mathrm{MI}$ sodium fluoride or monoidoacetate and markedly stimulated by adding $10^{-3} \mathrm{M}$ of thyroxine (Tables 7 and 8).

3. Intracellular glucose and cell glucose space. At a medium glucose concentration of $400 \mathrm{mg} / 100 \mathrm{ml}$ the presence of free intracellular glucose could be demonstrated with a statistical significance using $\mathrm{U}_{-}{ }^{14} \mathrm{C}$ sucrose and $\mathrm{H}_{2} \mathrm{O}^{3} \mathrm{H}$. Intracellular glucose levels rose when medium glucose concentration was increased to $600 \mathrm{mg} / 100 \mathrm{ml}$. By way of the cell glucose space (380 $\mu \mathrm{l} / \mathrm{ml}$ cell water) it was possible to demonstrate

Table 8. Glucose uptake of isolated human lencocytes under different experimental conditions

\begin{tabular}{|c|c|c|c|c|c|}
\hline $\begin{array}{l}\text { Medium } \\
\text { glucose } \\
\mathrm{mg} / 100 \mathrm{ml}\end{array}$ & $\begin{array}{l}\text { Number of } \\
\text { experiments }\end{array}$ & Additions & Incub. Period & $\begin{array}{l}\text { Glucose } \\
\text { uptake of } \\
\text { controls } \\
\mu \mathrm{mol} / 10^{10} \\
\text { cells } / \mathrm{h}\end{array}$ & $\begin{array}{l}\text { Changes in \% } \\
\text { of controls }\end{array}$ \\
\hline 200 & 5 & & $\begin{array}{r}0-30 \mathrm{~min} \\
30-60 \mathrm{~min} \\
60-120 \mathrm{~min} \\
120-180 \mathrm{~min} \\
180-240 \mathrm{~min}\end{array}$ & $\begin{array}{l}410 \pm 74 \\
405 \pm 65 \\
395 \pm 37 \\
345 \pm 29 \\
261 \pm 18\end{array}$ & \\
\hline $\begin{array}{l}200 \\
200 \\
200 \\
600 \\
200\end{array}$ & $\begin{array}{r}12 \\
8 \\
8 \\
8 \\
5\end{array}$ & $\begin{array}{l}\text { Insulin } 0.1 \mathrm{U} / \mathrm{ml} \\
\text { Insulin } 0.5 \mathrm{U} / \mathrm{ml} \\
\text { Insulin } 1.0 \mathrm{U} / \mathrm{ml} \\
\text { Insulin } 0.5 \mathrm{U} / \mathrm{ml} \\
\text { NaF } 5 \times 10^{-3} \mathrm{~m}\end{array}$ & $\begin{array}{l}60 \mathrm{~min} \\
60 \mathrm{~min} \\
60 \mathrm{~min} \\
60 \mathrm{~min} \\
60 \mathrm{~min}\end{array}$ & $\begin{array}{l}410 \pm 44 \\
430 \pm 80 \\
417 \pm 65 \\
484 \pm 86 \\
460 \pm 63\end{array}$ & $\begin{array}{l}+17.1 \% \text { n.s. } \\
+\quad 5.9 \% \text { n.s. } \\
+11.8 \% \text { n.s. } \\
+12.2 \% \text { n.s. } \\
-39 \%<0.01\end{array}$ \\
\hline 200 & 5 & $\begin{array}{l}\text { Monoiodoacetate } \\
5 \times 10^{-3} \mathrm{~m}\end{array}$ & $60 \mathrm{~min}$ & $440 \pm 72$ & $-61 \%<0.01$ \\
\hline $\begin{array}{l}200 \\
200\end{array}$ & $\begin{array}{l}5 \\
5\end{array}$ & $\begin{array}{l}\text { NaCN } 5 \times 10^{-3} \mathrm{~m} \\
\text { Thyroxine } 10^{-3} \mathrm{~m}\end{array}$ & $\begin{array}{l}60 \min \\
60 \min \end{array}$ & $\begin{array}{l}392 \pm 69 \\
398 \pm 60\end{array}$ & $\begin{array}{l}+13 \% \text { n.s. } \\
+36 \%<0.05\end{array}$ \\
\hline
\end{tabular}

Leucocyte suspensions of one preparation were divided for these experiments and the substance to be tested was added to one of the two samples. Results are reported as mean and standard deviation of controls without addition, changes by additions as $\%$ of controls. Significance was calculated using the $t$-test.

significantly during incubation or under the influence of insulin. In diabetics the mean was only slightly but not significantly higher than in control subjects. In leucocytes the intracellular distribution space for glucose is therefore as large as in animal heart muscle but 10 times larger than in rat adipose tissue (Crofford and Renold) [4]. Conditions in these cells are therefore that no equilibration between cell and medium concentrations takes place at these high extracellular glucose levels. Insulin doses of $100 \mathrm{mU} / \mathrm{ml}$ did not significantly affect intracellular glucose and cell glucose space.

4. Transport and phosphorylation of glucose. We have attempted to observe separately the processes of 
glucose uptake through the cell membrane and of glucose utilization. Basic considerations were: If the process of glucose uptake is designated as transport, disregarding the underlying mechanism, the rate of this process is identical to that of glucose uptake in all experimental conditions. Since accumulation of intracellular glucose is observed at medium concentrations above $200 \mathrm{mg} / 100 \mathrm{ml}$, we have to assume a back transport to the outside under these conditions which cannot be neglected. For the calculations of kinetic constants, only values for glucose uptake can therefore be used which have been determined at medium concentrations below $200 \mathrm{mg} / 100 \mathrm{ml}$. In this range glucose uptake rises steeply with increasing medium concentrations. Since according to Wilbrandt, under certain conditions of substrate saturation the data of Michaelis-Menten kinetics can show a nearly linear pattern in the lower part of the curve and cannot be differentiated with certainity from diffusion kinetics, no conclusions as to the kinetics of the process were possible from the curve obtained.

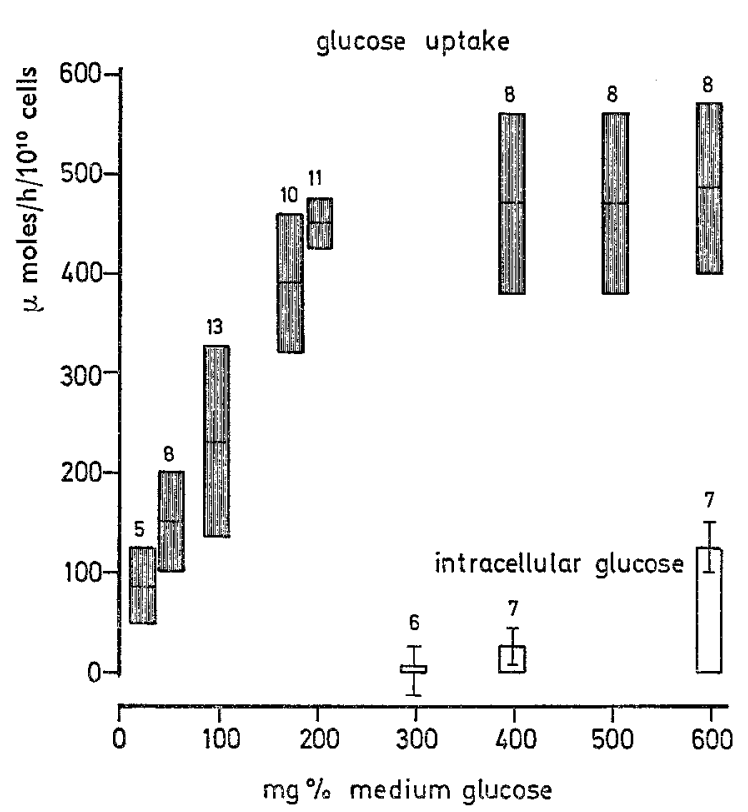

Fig. 1. Glucose uptake and intracellular glucose of isolated human leucocytes with increasing medium glucose concentrations. Incubation for $1 \mathrm{~h}$ at $37^{\circ} \mathrm{C}$ in $\mathrm{O}_{2} / \mathrm{CO}_{2}(95 / 5)$ in Krebs-Ringer bicarbonate buffer. Columns for glucose uptake $x \pm S$, figures above the number of subjects. Columns for intracellular glucose indicate mean values

Another procedure (see methods) has therefore been initially employed. We obtained data for outward transport due to intracellular glucose concentration, and thereby approximate values for inward transport representing the sum of glucose uptake and outward transport. The pattern of the curve showed that the rate of inward transport decreases with increasing medium concentrations. Wilbrandt [25] has observed and thoroughly studied similar phenomena in erythrocytes. These investigations led to the concept of a carrier mechanism for glucose transport through the cell membrane (Wilbrandt 1950/51, 1957, 1959, 1961), [25--28], predictions which agree well with experimental observations. If leucocytes also were to have such a transport system - an assumption still to be verified by other criteria (counter transport, competitive inhibition etc.) - kinetic data for inward transport can be calculated. We calculated constants according to the procedure described in the methodological part, and by inserting them into the transport equation a theoretical curve was plotted for inward transport. Its pattern agrees approximately with experimental data (Fig. 2).

The rate of phosphorylation can be equated to the rate of disappearance of free glucose from the medium. It can also be approximately calculated from glucose uptake corrected for the amount of intracellular glucose. At low glucose concentrations glucose uptake

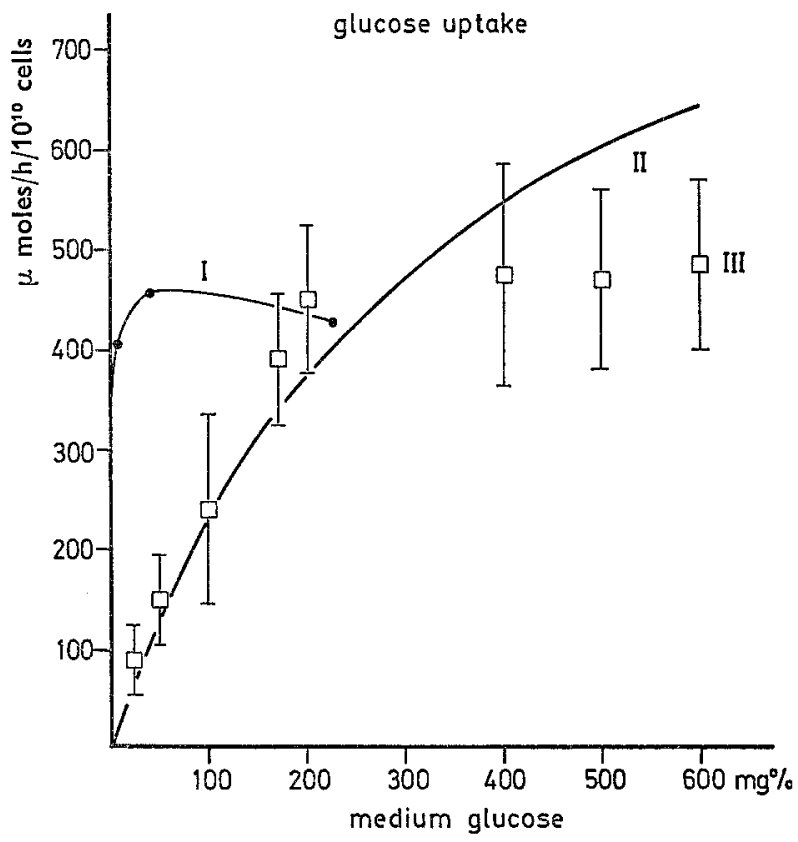

Fig. 2. Calculated curves for inward transport and phosphorylation of glucose as a function of medium glucose concentration. Values for inward transport have been calculated from the sum for uptake and back transport as described in 'Methods'. Rates of back transport were calculated based on experimentally determined intracellular concentration (see Methods). Kinetic data for inward transport have been obtained by linear transformation of these data according to Michaelis and Menten. Phosphorylation was determined from the difference of glucose uptake and intracellular glucose. To permit its comparison with transport, it has been plotted against external concentration

I = Phosphorylation (calculated from glucose uptake minus intracellular glucose

II = Theoretical curve of inward transport

III $=$ Glucose uptake as determined experimentally. 
corresponds rather closely to phosphorylation, since the low levels of intracellular glucose, which maintain phosphorylation in the cell and cannot be demonstrated experimentally, can be neglected.

According to Morgan et al. [20] it is also possible to estimate the limits the processes of transport and phosphorylation impose upon the system as a whole. The capacity of phosphorylation is obtained by plotting the data against intracellular glucose concentration. Assuming a theoretical state in which the cell membrane has been removed and in which external and internal glucose concentrations are identical, the curve of inward transport can be plotted in the same coordinate system (Fig. 2). It can now be seen, that at low medium concentrations the cell membrane limits the rate of phosphorylation, that this limitation diminishes with increasing concentrations and finally ought to become negative.

5. Lactate production. During incubation for one hour the lactate production also depended on extracellular glucose concentration (Table 7). The data demonstrate that - under the assumption that one mole of lactate is produced from one mole of glucose in human leucocytes - the largest part of glucose is utilized via glycolysis.

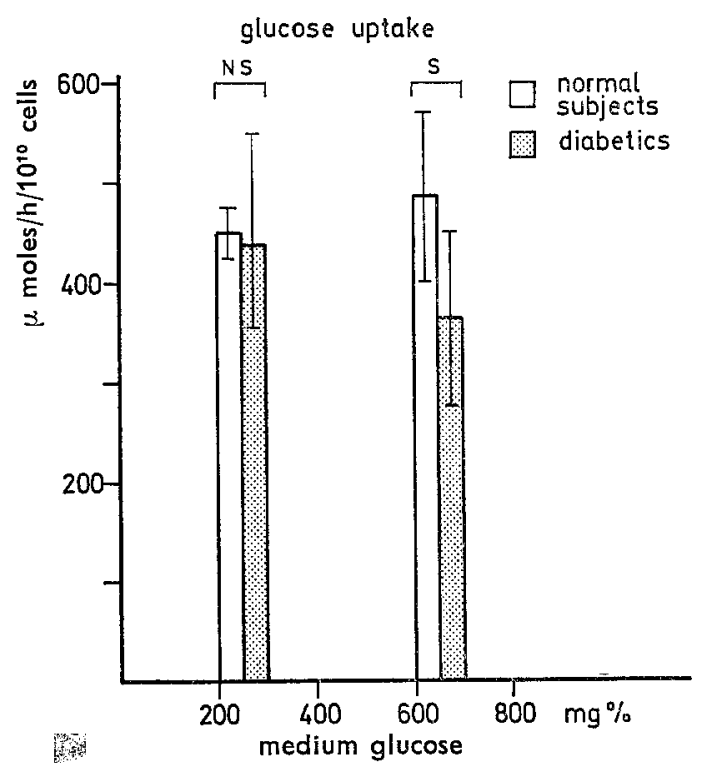

Fig. 3. Glucose uptake in leucocytes from control persons and diabetics (for patients and experimental details see 'Methods')

\section{B. Diabetics}

The parameters described above were also investigated in diabetics with clinical signs of metabolic decompensation who had not received insulin for $12 \mathrm{~h}$ prior to the experiment. At medium concentrations of $600 \mathrm{mg} / 100 \mathrm{ml}$ glucose uptake was significantly reduced in leucocytes from diabetics (Fig. 3). We found no alterations of the differential blood count which could have explained the diminution of glucose uptake on the base of different rates of glucose utilization in leucocytes and lymphocytes. Water spaces of cells from control subjects did not show significant differences either.

\section{Discussion}

As a model for investigations of glucose metabolism leucocyte preparations have the advantage that they can be obtained easily and without severe damage to their membranes, and moreover that their basal metabolism changes only slightly under conditions in vitro. Disadvantages are technical difficulties in the separation of the cells from the liquid phase, small volume of the cell material, relatively high variability of samples and slight to absent insulinsensitivity (Kalant and Schucher [14], Esman [12], Martinetz et al. [18]). During our experiments a significant insulin effect could not be demonstrated. The question must be discussed though, whether the rates for glucose metabolism without insulin in vitro can be regarded as true basal values, since it is not known how long insulin remains adsorbed to the membrane of leucocytes.

In order of magnitude glucose uptake of leucocytes is only slightly smaller than that of the isolated, perfused rat heart (averages: $4.12 \mathrm{mg} / \mathrm{g}$.h cell mass for leucocytes, $14.9 \mathrm{mg} / \mathrm{g} . \mathrm{h}$ for the isolated perfused heart according to Morgan et al.). It depends on extracellular glucose concentration as has been shown for adipose tissue by Crofford and Renold [5], for erythrocytes by Wilbrandt and Rosenberg [28] and for intestinal mucosa by Crane [2, 3]. Its capacity is limited and its rate cannot be accelerated beyond a certain threshold. $\mathrm{As}$ indicated by the appearance of free glucose in the cell and by the pattern of the curves for transport and phosphorylation, the capacity of phosphorylation is also limited. At high extracellular glucose concentrations it should therefore become the rate-limiting step for the entire system.

The pattern of the curve for the inward transport, which has been determined theoretically, shows that inward transport does not increase in proportion to rising extracellular concentrations. It would have to be discussed therefore, whether the carrier hypothesis can be applied to these cells, according to which glucose molecules are transported through the cell membrane as complexes. This hypothesis is supported. by the approximate agreement between the predictive curve calculated under this assumption and the experimental data. An exact comparison is not possible in the upper part of the curve since experimental data for inward transport cannot be obtained in this region. It can only be calculated, taking for granted that the transfer of glucose in both directions follows the same laws. The existence of a carrier-mechanism could only be proven if other phenomena such as competitive 
antagonism of different sugars, countertransport etc. are demonstrated as has been done by Wilbrandt for erythrocytes, by Morgan et al. [15, 19, 21] for rat heart muscle and by Crofford and Renold [4,5] for adipose tissue.

During severe episodes of diabetes the glucose uptake of leucocytes at a medium concentration of $600 \mathrm{mg} / 100 \mathrm{ml}$ was significantly reduced. In this respect our results fully confirm those of other authors. Martin et al. [18], however, have already observed this effect at $100 \mathrm{mg} / 100 \mathrm{ml}$ of extracellular glucose, whilst Esman [12] saw no significant differences with somewhat non-homogeneous groups of patients. Dumm [8, 9] noticed this only if he investigated diabetic patients requiring high insulin doses.

Selection of patients, pre-treatment of cells and choice of experimental conditions seem to affect the outcome. Possibly the duration of insulin withdrawal is also involved.

Since the alteration is found in a range in which transport factors can no longer affect the utilization, it is not possible to relate this effect to an impairment of the insulin-dependent transport-system. From the data it appears more likely that intracellular glucose utilization is impaired in the cells of diabetic patients. Other investigators have noticed a diminished capacity of glucose utilization at the phosphorylation level in alloxan-diabetic animals (Kipnis, Helmreich and Cori [16], Morgan et al. [20]). This does not necessarily indicate an impairment of the hexokinase reaction. Secondary effects could also be due to an accumulation of glucose-6-phosphate as a consequence of an impaired phosphofructokinase reaction.

\section{References}

1. Bray, G.A.: A simple efficient liquid scintillator for counting aqueous solutions in a liquid scintillation counter. Anal. Biochem. 1, 279 (1960).

2. Crane, R.K.: Intestinal absorption of sugars. Physiol. Rev. 40, 789 (1960).

3. - Studies on the mechanism of the intestinal absorption of sugars. III. Mutual inhibition in vitro between some actively transported sugars. Biochem. biophys. Acta 45, 477 (1960).

4. Crofford, O.B., Renold, A.E.: Glucose uptake by incubated rat epididymal adipose tissue. Characteristics of the glucose transport system and action of insulin. J. biol. Chem. 240, 3237 (1965).

5. - - Glucose uptake by incubated rat epididymal adipose tissue. Rate limiting steps and site of insulin action. J. biol. Chem. 240, 14 (1965).

6. Doerffel, K. : Beurteilung von Analysenverfahren und -Ergebnissen. Berlin-Heidelberg-New York: Springer 1965.

7. Dowd, J.E., Riggs, D.S.: A comparison of estimates of Michaelis Menten kinetic constants from various linear transformations. J. biol. Chem. 240, $863(1965)$.

8. Dumm, M.: Effect of tolbutamide on glucose uptake by leukocytes of patients with diabetes mellitus. J. appl. Physiol. 14, 1023 (1959).
9. - Glucose utilization and lactate production by leukocytes of patients with diabetes mellitus. Proc. Soc. exp. Biol. (N.Y.) 95, 571 (1957).

10. Engelhardt, A., Görlich, H.: Stoffwechseluntersuchungen an weißen Blutzellen. III. Über die Ursachen des Enzymverlusts der Zellen. Klin. Wschr. 42, 1184 (1964).

11. - Untersuchungen von Stoffwechselvorgängen an menschlichen weißen Blutzellen. I. Enzymmuster der weißen Blutzellen Gesunder. Klin. Wschr. 42, 1141 (1964).

12. Esman, V.: Effect of insulin on human leukocytes. Diabetes 12, 545 (1963).

13. Hohorst, H.J., Kreutz, F.H., Bücher, Th.: Über Metabolitgehalte und Metabolitkonzentrationen in der Leber der Ratte. Biochem. Z. 332, 18 (1959).

14. Kalant, N., Schucher, R.: Glucose utilization and insulin responsiveness of leukocytes in diabetics. Canad. J. biochem. Physiol. 40, 899 (1962).

15. Kipnis, D.M.: J. biol. Chem. 262, 236 (1961). Ann. N.Y. Acad. Sci. 82, 354 (1959). zit. n. Morgan, Cadenas, Regen and Park.

16. - Helmreich, E., Cori, C.F.: J. biol. Chem. 234, 165 (1959) zit. n. Morgan, Cadenas, Regen and Park J. biol. Chem. 262, 236 (1961).

17. Lacko, L., Burger, M., Hejmova, L., Rejulkova, J.: Membrane transport and metabolism. Symposium in Prag, Aug. 1960. Edit. Kleinzeller and A. Kotyk, London and New York: Academic Press. p. 399/407.

18. Martin, S.P., Me Kinney, G.R., Green, R., Becker, C.: The influence of glucose, fructose and insulin on the metabolism of leukocytes of healthy and diabetic subjects. J. clin. Invest. 32, 1171 (1953).

19. Morgan, H.E., Henderson, M., Regen, D.M., Park, C.R.: Regulation of glucose uptake in muscle. I. The effects of insulin and anoxia on glucose transport and phosphorylation in the isolated perfused heart of normal rats. J. biol. Chem. 236, 253 (1961).

20. - Cadenas, E., Regen, D.M., Park, C.R. : Regulation of glucose uptake in muscle. II. Rate limiting steps and effects of insulin and anoxia in heart muscle from diabetic rats. J. biol. Chem. 262, 236 (1961).

21. - Regen, D.M., Park, C.R.: Identification of a mobile carrier mediated sugar transport system in muscle. J. biol. Chem. 236, 369 (1961).

22. Partridge, S.M.: Nature (London) 164, 443 (1949) zit. n. Morgan, Henderson, Regen and Park J. biol. Chem. 236, 253 (1961).

23. Post, R.I., Morgan, H.E., Park, C.R.: Regulation of glucose uptake in muscle. III. The interaction of membrane transport and phosphorylation in the control of glucose uptake. J. biol. Chem. 236, 269 (1961).

24. Weinberg, A.N., Field, N.: Effect of insulin on the metabolism of white blood cells from normal and diabetic subjects. Clin. Res. 7, 247 (1959).

25. Wilbrandt, W.: Permeabilitätsprobleme Arch. f. experimentelle Pathol. und Pharmakologie 212, 194 $(1950 / 51)$.

26. - Permeabilität, aktiver Transport und Trägermechanismus. Dtsch. med. Wschr. 28, 1153 (1957).

27. - Transportsysteme für Zucker. Moderne Probleme der Pädiatrie. Basel, New York: S. Karger, Separatum Vol. IV (1959).

28. - Rosenberg, T.: The concept of carrier transport and its corollaries in pharmacology. Pharmacol. Rev. 13, 109 (1961).

Prof. Dr. A. Englhardt

Med. Univ.-Klinilk

BRD-3550 Marburg/Lahn

Mannkopffstr. 1

Deutschland 